\title{
Union Membership and Job-Related Training: Incidence, Transferability, and Efficacy
}

C. Jeffrey Waddoups* Department of Economics University of Nevada, Las Vegas 4505 South Maryland Parkway

Las Vegas, NV 89154-6005

Phone: 702-895-3497

Fax: 702-895-1354

Email: Jeffrey.Waddoups@unlv.edu

*The author also holds an adjunct associate professor position with the Department of Management at Griffith University, Brisbane, QLD, Australia. 


\begin{abstract}
"Union Membership and Job-Related Training:

Incidence, Transferability, and Efficacy"
\end{abstract}

[Word Count 9,852]

This study examines the relationship between union membership and 1) the incidence of training, 2) the degree to which training is transferable to firms other than the one providing the training, and 3) the degree to which workers perceive that training improves job performance. Using data from the Australian Bureau of Statistics, I find that union members are more likely to receive employer-sponsored training than their nonunion counterparts. I also find that male union members are more likely than nonmembers to report that training improved job performance. Union membership was not related to transferability of skills between employers. 


\section{Introduction}

Employer-sponsored training is an important component of advanced economies' human capital stocks. To the extent that such skill formation plays a significant role in determining an economy's growth potential, it is important to understand factors that underlie an economy's commitment to training. Against this backdrop, the present study focuses on the impact of trade union membership on the three dimensions of training: first, whether union membership is correlated with the incidence of training; second, whether union membership affects the mix between transferable and firm-specific training; ${ }^{1}$ and third, whether union membership is related to workers' perceptions about the efficacy of training, or the relationship between training and job performance.

The study is informed by theoretical literature on the impact of unions on training incidence, beginning with standard human capital theory, which predicts that union wage policies reduce incentives for firms to sponsor training (e.g. Becker 1962). More recently, theoretical developments, which account for imperfect competition, suggest that unionised environments may increase incentives for firms to sponsor training (Booth and Chatterji 1998; Acemoglu and Pischke 1999). Although the data are too limited for the present analysis to definitively distinguish between competing theoretical predictions about training incidence, they nevertheless are sufficient to provide additional evidence to the growing literature on union training effects.

Besides the influence of unions on the incidence of training, the study also addresses the relationship between unionism and whether workers receive general or transferable skills in their training courses, and whether union membership is related to

\footnotetext{
${ }^{1}$ Although the literature distinguishes between general and transferable training (e.g. Stevens 1994), I combine the two categories for the purposes of the present study.
} 
workers' perceptions about training and job performance. Previous research suggests that a large majority (roughly 85 per cent) of firm-sponsored training is either general or transferable between employers, while the remainder is firm-specific (Booth and Katic 2011; Booth and Bryan 2005). The question about whether unionisation affects the mix between the two, however, has not been directly studied either theoretically or empirically. ${ }^{2}$ In addition, there has been very little research on the effectiveness of training from the standpoint of the trainee taking into account union status. One may reasonably expect union membership to enhance the effectiveness of firm-sponsored training to the extent that it provides workers with more voice in determining the content of training courses and how they are delivered. On the other hand, perhaps union agreements, which often are in force for considerable lengths of time, institutionalise training programmes or practices that become progressively inconsistent with the production process. In such cases, one may expect a negative influence of unionism on the perception of effectiveness among union members.

The remainder of the paper is organised as follows. The next section reviews the theoretical and empirical literature on union training effects. After the review, I will discuss the data, which come from the Survey of Education and Training 2005 (SET), a cross-sectional, random sample of Australian households gathered quadrennially by the Australian Bureau of Statistics (ABS). Then empirical models will be proposed, estimated and discussed, emphasizing union effects on incidence, transferability, and efficacy of training. Finally, I conclude and draw implications for future research.

\footnotetext{
${ }^{2}$ Relatedly, however, Askildsen and Ireland (1993) theoretically examine the mix between specific and general training that would occur in labour-managed versus profit maximizing firms.
} 


\section{Theoretical Background and Previous Empirical Results}

\section{Training and Human Capital Theory}

Previous studies have outlined a number of approaches to understanding the relationship between unionism and firm-sponsored training. ${ }^{3}$ Clear theoretical predictions about the incidence of training emerge from the standard human capital model. The theory suggests that because unions install a floor on wages early in the employment relationship, liquidity constrained workers are precluded from paying for their training by taking lower wages during the training period. Such flattening of the wage-tenure profile reduces the likelihood that firms will invest in general training, especially in an otherwise competitive environment when labour market competition is expected to bid post-training wages toward marginal product (Becker 1962). The wage distortions result in less general training being provided and in a suboptimal level of job-related general training.

The logic also holds for firm-specific training in which firms and workers share both the costs of and returns to training (Hashimoto 1981). Higher union wages at the beginning of the employment relationship are predicted to reduce the likelihood that firms will find future returns on specific training high enough to out-weigh the higher proportion of costs they must cover during the training period. The first row in Table 1 contains theoretical predictions on the union-training effect associated with the human capital approach.

\section{Table 1 about here}

\footnotetext{
${ }^{3}$ See also Booth, Francesconi, and Zoega (2003), which provides a useful review of how theoretical differences in the link between unionism and training lead to variation in empirical expectations.
} 
Consistent with standard human capital theory, empirical research by Mincer (1993) using 1976-79 Panel Survey of Income Dynamics (PSID) data found a negative correlation between unionism and the length of time for workers to become fully trained for their job. Although the training question in the PSID data does not ask directly about participation in training programmes, the longer time period to become fully qualified suggests that more training occurs in the non-union sector. More recently, research using individual-level cross-sectional data from the Canadian Adult Education and Training Survey from 1997 detects a small negative union-training effect, which is also consistent with predictions from the human capital approach (Green and Lemieux 2007). Along similar lines, weaker evidence suggesting less training in unionised settings was reported by Barron, Black and Loewenstein (1987). They used employer-level data from the Employment Opportunity Pilot Project (EOPP) sponsored by the U.S. Department of Labor on the last person hired, to find a negative, though statistically insignificant, coefficient on the union variable in a training incidence equation. ${ }^{4}$

\footnotetext{
${ }^{4}$ The empirical literature consists of studies using both individual-level and firm- or establishment-level data. On the one hand, individual-level data are useful for estimating determinants of training because they often have extensive information on personal characteristics that firm-level data do not have. On the other hand, to the extent that the decision of whether to train is made by negotiation between unions and firms, and workers themselves have limited input, then it would be useful to estimate union-training effects using firm- or establishment-level data. In some cases both are found in the same data set. Data sets such as the Workplace Employment Relations Survey (WERS) from Britain and the Australian Workplace Industrial Relations Survey (AWIRS) are examples (e.g. Almeida-Santos and Mumford 2004, 2005). As with much of the empirical work in the social sciences, the choice of data is often based on availability. For example, the latest iteration of the AWIRS data is 1995, which means that more recent estimates of the union training effect would need to be conducted using data at the individual level, such as the Survey of Education and Training (SET) used in the present study. When using individual-level data such as the SET, the union membership variable may only imperfectly capture the actual union effect, because some non-union workers may be trained based on influence from union bargaining in their workplaces. In such cases, it is likely that the union effect will be somewhat understated, everything else equal.
} 


\section{Training with Imperfect Competition}

In contrast to the human capital model, more recent theoretical work, which accounts for labour market imperfections, suggests that the impact of unions on training may either be positive or negative. According to Acemoglu and Pischke (1999), it would be reasonable to expect an increased incidence of firm-sponsored general training under conditions of wage compression. Wage compression occurs, in part, when institutional interventions keep starting wages higher than would otherwise be the case, and in part when firms have some monopsony power over its workforce, which causes post-training wages to be below productivity and lower than would be predicted under perfect competition. For firms to increase the amount of general training that they finance, however, the wedge between wages and productivity must grow larger as the level of skill from the training investment increases. Union bargaining and wage setting is one avenue by which such conditions can be created. For example, it has been well documented that unions may find it in their interest to create compression for political or ideological reasons, or perhaps to maintain solidarity within the bargaining unit (e.g. Freeman and Medoff 1984).

Just as wage compression may increase the likelihood of training, by reducing the returns to general or transferable training (the monopsony power effect), it also reduces the incentive for workers to invest because of lower expected future returns. The prediction from the workers' perspective, therefore, is that there will be less training under a unionised environment with wage compression, leaving the overall effect of unions on training ambiguous. 
Rather than focusing on wage compression, Booth and Chatterji (1998) and Chatterji (2008) model the training decision as one in which unions at the enterprise level raise bargaining power of trained workers, which raises their wages and reduces quits. With fewer quits firms are less likely to lose their training investment to other firms, providing them with an incentive to provide more training than otherwise would have been the case. Similarly, when unions bargain over training levels at an industry-wide level, firms have an incentive to choose higher levels of training that are closer to the social optimum. Left on their own, individual firms would provide less training, because they do not benefit from the training provided to workers who quit, fully trained, and become employed with a competitor (see Table 1 for a summary). Union bargaining in essence internalises the training externality and increases the optimal training level (Booth, Franscesconi, and Zoega 2002). ${ }^{5}$

Consistent with the theoretical literature on training and imperfect competition, studies using data from the U.K. generally find that union coverage is positively related to training. For example in earlier work, Booth (1991) found that both male and female workers covered by unions are more likely to have participated in a training course during the previous two years starting in 1987. Later, using the British Household Panel Survey (BHPS), Booth, Franscesconi, and Zoega (2003) reached a similar conclusion, finding that union-covered workers are approximately nine per cent more likely to receive training than the non-covered. The estimate of the union-training effect fell to just

\footnotetext{
${ }^{5}$ Although higher levels of quits may conceivably lead to more training, because of the need to provide induction training to new employees, Waddoups (2011a) shows that the incidence of training is relatively uniform across the employee tenure profile. This suggests that much of the training is not going to new employees. Other research using the SET from 2001 shows that induction training was only 7.0 per cent of in-house training and 3.0 per cent of external training (Waddoups 2011b).
} 
over five per cent, but remained statistically significant, when unobserved heterogeneity was controlled for using panel data methods.

A number of empirical studies based on data from the U.S. have also found a positive impact of union coverage on the probability of training. Lynch (1992) reported a positive impact when estimating incidence equations in the National Longitudinal Survey of Youth (NLSY), but because only training spells lasting longer than a month are observed, many shorter training spells were likely to have been missed. Veum (1995) continued the research using later waves of the NLSY that observed all training spells regardless of duration and still found a positive correlation between union coverage and the incidence of training. A potential drawback in using the NLSY, however, is that the age cohort limits the generalisability of the study. Between 1986 and 1990 the respondents were 21-29 in 1986 and 25-33 in 1990. Osterman (1995) used establishmentlevel data, which were randomly drawn from establishments in the U.S., to observe training among non-managerial, non-supervisory employees. He reported a positive relationship between training and union presence in the establishment.

A study in Australia confirmed a positive union-training effect using combined individual- and establishment-level data drawn from the 1989-90 Australian Workplace Industrial Relations Survey (AWIRS) [Kennedy et al. 1994]. Particularly interesting are the results showing that union membership per se had no impact on the incidence of training. The presence of union delegates in the workplace, which presumably signals a more active union presence, however, did correlate positively with training. Thus an active union presence, rather than passive union membership, had a positive impact on training in Australia during the period between 1989 and 1990. Although later research 
using AWIRS from 1995 found no union training effect, the model specifications in the two studies are not the same, which limits their comparability (Almeida-Santos and Mumford 2004).

\section{Training as Compensation}

Another possibility is that unions see training as a part of the compensation package to be obtained through bargaining (Booth, Franscesconi, and Zoega 2003). If workers’ economic interests are furthered by the amount and nature of employer-sponsored training made available, then unions may be expected to negotiate for more training. For example, it is reasonable to expect that the median worker would be interested in training that could increase employment security and perhaps wages. Furthermore, although firms under competitive conditions may be, theoretically, reluctant to pay for general or transferable training, union bargaining power could overcome such reluctance by simply causing firms to perceive the provision of training not necessarily as an investment, but as part of the compensation package.

\section{Implications for Union Training Effects}

Clearly, the review of the various theoretical approaches implies ambiguous predictions about the union-training effect. On the one hand, from the orthodox human capital perspective, which assumes competitive labour markets, one would expect that unioninduced flattened wage-tenure profiles reduces the likelihood that firms would invest in either specific or general training. On the other hand, when assumptions of competitive labour markets are relaxed along the lines of wage compression models [e.g. Acemoglu 
and Pischke (1999)] or increased bargaining power, higher wages, and reduced quits [e.g. Chatterji (2008)], theoretical space is cleared for the expectation that unions increase the likelihood of training. Similarly, unions could conceivably increase the likelihood that firms provide training simply as part of an enhanced compensation package made possible by union bargaining power. In light of the ambiguous theoretical predictions, it is perhaps not surprising that empirical results as reviewed above have also been mixed.

The literature review also highlights the methodological differences between the various studies, which also undoubtedly contributes to the mixed results on the union training question. Referring to Table 2, which summarises the essential elements of the studies reviewed, notice that the definition of training ranges widely from the time it takes a worker to become fully trained (Mincer 1993) to employer provision of formal training courses (e.g. Almeida-Santos and Mumford 2004). The national origin of the data sources used, the way training is operationalised, the level of analysis (individual level v. establishment level) and the time frame also varies across studies, as does the way union status is defined. Such variation makes it difficult to draw any firm conclusions about broader patterns of relationships between unions and job training across studies and countries.

Table 2 about here

Although there has been some empirical research on unions and training based specifically on Australian data, the structure of collective bargaining in Australia suggests at least two difficulties in arriving at clean estimates of the union training effect. ${ }^{6}$ First, union membership of the individual worker, which is the indicator of unionism in the empirical portion of the present study, is an imperfect indicator of union activity in the

\footnotetext{
${ }^{6}$ Cai and Waddoups (2011) provide a brief overview of the structure of collective bargaining in Australia.
} 
workplace. Union members in workplaces with active unions are likely to experience union effects differently than union members in workplaces where union activity is less pronounced (Kennedy et al. 1994). Second, because there is no compulsory unionism in Australia, union members and non-members may work side-by-side while the impact of training policies established through the influence of collective bargaining may flow to union members and non-members alike. The fact that employment policies that may be affected by unions do not accrue only to union members tends to bias estimates of the union effect toward zero. Although such difficulties are a possibility, there appears to be enough distinction between union and non-union workers in the data to detect union effects. For example, evidence from the literature on union wage effects using Australian data, suggests that there is still enough of a distinction between union members and nonmembers using individual-level data to arrive at a positive union wage effect (Cai and Liu 2008; Cai and Waddoups 2011).

\section{Data: The Survey of Education and Training 2005}

The data originate from the 2005 installment of the ABS's SET. The SET is composed of observations from a random sample of Australian households. Questions in the survey generate information on household members' job training, other human capital investments, the size of employers, and other variables generally controlled for in labour market analyses. The sampling frame used in the present analysis consists of individuals of working age, defined as ages 15-64. The samples are further limited to respondents who were working for their main period employer, who were not self-employed or 
working for a self-owned business, and who were not full-time students. ${ }^{7}$ After the exclusions, the final samples contain 6,131 males and 6,086 females.

Proportions of workers engaging in two types of training by sex and union membership are located in Table 3. The variable 'In-House Training' observes whether the respondent reports at least one in-house training course during the previous 12 months. Such training consists of formal training courses conducted by either the employer or a consultant hired by the employer for the purpose of providing training. ${ }^{8}$ Table 3 shows that 50.4 per cent of male union members participated in in-house training compared to non-members, who trained at a rate of 30.4 per cent. The corresponding numbers for females are 59.4 and 32.7 per cent. For males and especially females, union members are much more likely to have participated in at least one in-house training course over the previous 12 months. Table 3 also shows very little difference in the rates of external training by sex and union status. Employees participate in external training courses less frequently than in-house courses, and there are smaller differences based on union status. Figures in Table 3 show that 27.6 per cent of male union members engaged in external training compared to 29.2 per cent for non-members. For females the numbers are 30.8 and 26.9 per cent for union members and non-members, respectively.

\footnotetext{
${ }^{7}$ The ABS uses standard question modules in the SET surveys, which makes the results largely comparable to other surveys they conduct, such as Labour Force Australia. See ABS (2006) for a detailed description of the SET data.

${ }^{8}$ To construct the training incidence measures, respondents were asked whether they participated in any work-related training courses during the 12 months prior to the interview. Work-related training is defined as "work-related learning activities, undertaken primarily to obtain, maintain or improve employmentrelated skills or competencies. More specifically, work-related training for the purposes of the SET were "undertaken in Australia," and "had a structured format, with an orderly or methodical means of presenting or providing the training during a period of time." Examples of work-related training include: "training seminars, training workshops and other group training sessions; demonstration training sessions and training conferences; audio visual presentations and talks or lecture presentation and classroom-style presentations or self-paced training courses." "In-house" training is organised and delivered by the employer or a consultant hired by the employer for the purpose of training. "External" training courses are organised by outside providers (ABS 2006: 87).
} 
Table 3 about here

Table 3 also reports estimates of the percentage of workers receiving training they considered transferable to other firms. The 'Transferable' variable was generated from a question that asked respondents who reported training whether "skills gained could be used with another employer" or "skills gained could not be used with another employer." The variable, however, should be treated with caution because it contains a counterfactual, which adds to the possibility of measurement error. The respondents are asked about training being transferable, which is something that by definition has not occurred. That is, they have not taken the training received by the current employer to another one. This question on transferability is different than the training incidence question, because in the previous 12 months training either did or did not occur.

A large majority of workers indicate that their training is transferable, and there is not much difference between union members and non-members. ${ }^{9}$ Notice that the finding holds for both in-house and external training, which suggests that defining in-house training as firm-specific and external training as general is not an accurate characterization. It is also interesting to note that a large majority of both training types are financed by employers, which also runs counter to standard human capital theory, but is consistent with other research (e.g. Booth and Bryan 2005; Booth and Katic 2011). Standard theory predicts that transferable training should be financed by trainees. Although the method of financing may be lower wages than would otherwise be the case during the training period, which tends to disguise the worker as the actual source of payment, it is clear that a large majority of workers do not believe that they are paying for

\footnotetext{
${ }^{9}$ Booth and Bryan (2005) find comparable results in the BHPS where they report that 85 per cent of training schemes impart general skills. See also Booth and Katic (2011) who find that a large majority of private sector males in Australia report their job-training to be transferable to other employers.
} 
their transferable training. Furthermore, given that many of the trainees are longertenured workers, it does not seem plausible to argue that their wages are somehow adjusted to finance transferable training (Waddoups 2011a).

A similarly large percentage of respondents are optimistic about the quality of their training, indicating that it improved their job performance. The variable on job performance was generated from a question in the SET that asks respondents who have completed at least one training program whether "training has improved job performance," or "training has not improved job performance." There are no objective measures about actual changes in job performance in the survey; therefore, this variable only measures workers' subjective experience. The results point to slightly more male union members who report that training improved their job performance than nonmembers. The percentages are roughly the same for union and non-union female workers. Although almost no workers report incurring costs for in-house training, the percentage reporting costs incurred for external training ranges from 14.1 per cent for unionised males to 20.1 per cent for unionised females.

The results in Table 4 demonstrate that individual and job characteristics vary substantially among union and non-union workers. Union members are older and have been with their employers and in their occupations longer. Compared to non-members, male union members are less likely to hold a bachelors degrees (9.6 compared to 14.2 per cent), whereas among females the results are reversed (21.8 compared to 15.9 per cent). The differences in firm size among union and non-union workers are striking: 78.9 per cent of male respondents reporting union membership are employed in firms with 100 or more employees. The corresponding number for females is similar at 77.6 per cent. Of 
those reporting non-union status roughly half are employed with larger employers (100 or more workers). Union members also tend to be disproportionately employed in the public sector, in non-casual jobs, and in full-time employment.

Table 4 about here

\section{Empirical Model and Estimation Results}

By estimating a model of the determinants of training while controlling for unionism and other variables that may affect the training decision, it is possible to establish a more complete view of the relationship between union membership and training. The empirical strategy is to estimate the probability of training $(P)$ using a maximum likelihood probit procedure according to the following:

(1) $P=\alpha+\beta($ Union Member $)+\delta X+\varepsilon$,

where $P$ represents the probability of training in the previous 12 months, "Union Member" represents a dummy variable that takes on the value ' 1 ' if the respondent is a union member and ' 0 ' otherwise, $X$ is a vector of other variables that may affect the probability of training, $\beta$ and $\delta$ are parameters to be estimated and $\varepsilon$ is a random error term.

Incidence of In-House Training

A series of three specifications are used to estimate the probability of in-house training, external training, and then a combination of the two. The three specifications are 
estimated separately for males and females. The first specification controls for union status, age, tenure with employer, tenure within occupation and education; the second adds controls for characteristics of jobs (i.e. firm size, public sector, casual status, and part-time status); the third adds demographic dummies (e.g. marital status, etc.) and controls for state, occupation, and industry.

The first specification located in Table 5 is estimated using data for only males. It indicates that union members are 18.3 percentage points more likely to engage in inhouse training than non-members. As more controls are added, the union coefficient becomes smaller, suggesting that unionism is positively correlated with a number of observed factors that are positively correlated with the probability of training. Notice that the biggest drop in union effect occurs when controls for job-related factors are added in Specification 2. The union effect drops from roughly 18 percentage points to 8.7 , but retains its statistical significance. Adding the rest of the demographic, state, occupation and industry variables exerts very little additional downward effect on the union coefficient.

\section{Table 5 about here}

As discussed in the literature review (also see footnote 4), the union membership variable may imperfectly capture the actual union training effect, because some nonmember workers in more highly unionised workplaces may receive training by virtue of spillovers from union bargaining. This is a possibility because the lack of compulsory unionism in Australia allows for union members and non-members to work side-by-side and be affected by union-influenced employment policies in the same way. Such 
circumstances suggest that it would be reasonable to consider the 8.7 percent union training advantage as understating the actual union effect. ${ }^{10}$

Other variables of interest also have a significant influence on the probability of in-house training. For example, age increases the likelihood of training, but the effect decreases over time. Larger firms, especially those with 100 or more workers, are much more likely to conduct in-house training than smaller ones. Workers in casual jobs are less likely to train, while those in the public sector are more likely to train.

Results of the same analysis are reported for female workers in the second panel of Table 5. The findings exhibit a substantially larger union-training effect. The first specification indicates a 23 percentage point in-house training advantage to union members. The union effect drops off sharply to 14.1 percentage points when job-related variables are added to the estimating equation (see Specification 2). Adding the remaining demographic, state, occupational and industry variables exerts only a mild negative effect on the union coefficient. The most complete specification indicates a 13.5 percentage point advantage to union members.

\section{Incidence of External Training}

Results on the union-training effect when the training in question is external are reported in Table 6. For males, the coefficient on the union variable is negative, but quite small and doesn't reach conventional levels of significance. The coefficient remains relatively small as more complete specifications are estimated. In the most complete specification, the probability of external training is roughly 2.6 percentage points lower for union

\footnotetext{
${ }^{10}$ On the other hand, the discussion of endogeneity, which occurs later in the paper, argues that the union effect may be overstated.
} 
members compared to non-members. The positive union effect in Table 5 compared to the negative effect in Table 6 suggest that higher rates of external training in non-union settings may to some extent offset the lower levels of internal training, although the lack of statistical significance in the 'external' equations weakens the conjecture. Taken together the evidence supports the notion that unionised workers have a higher probability of training overall than their non-union counterparts.

Table 6 about here

The pattern of union-training effects for external training among females differs from that of males. The second panel of Table 6 shows very small and statistically insignificant union effects in all three specifications. Thus it appears that union membership does not affect the probability of external training for females either. Combining the results of Tables 5 and 6, one must infer that female union members train much more extensively than non-members. That is, they are roughly 13.0 probability points more likely to participate in in-house training courses and the two groups have roughly the same likelihood of training externally.

It is reasonable to expect that firms substitute between in-house and external training based on such factors as competitive conditions and economies of scale and scope in training. For example, consider the results for men in Tables 5 and 6 where the union coefficient on the in-house training equation is positive while the one in the external equation is negative. It may be that union members receive their training mostly in-house and non-members through external sources, but that when combined there is not a significant difference in the total amount of training between the two groups. Such a possibility suggests that combining the two training variables into one overall training 
incidence variable, that takes on the value ' 1 ' if either in-house or external training has occurred and ' 0 ' otherwise, may provide a clearer picture of the overall training picture. Table 7 contains estimations of a combined training incidence variable.

Table 7 about here.

When the training variables are combined, the union effect is still positive and statistically significant for both males and females, but the magnitude drops in both cases. For males the union membership is associated with 0.047 additional probability points and for females the figure is 0.106 .

\section{Endogeneity}

The union-training effects reported in Tables 5-7 should be treated with caution, because the union variable may be endogenously determined. As is often the case in empirical research on union effects, there is not a good instrument available to control for endogeneity. In this instance, the endogeneity problem occurs when unobserved factors (say ability and motivation) that may be positively correlated with union membership may also be positively correlated with the probability of training. Endogeneity may arise because firms search more diligently for higher quality workers (who are more likely to train) for union-covered jobs, or because higher quality workers self-select into union membership. Without a way to control for such unobserved factors, the estimate of the union effect will likely be biased upward.

One way to address endogeneity is to find an instrument for union membership. A good instrument is a variable that is correlated to union membership for reasons that the researcher can verify and explain, but which is uncorrelated with training (Angrist and 
Krueger 2001). In cross-sectional data sets, good instruments for union membership are difficult to find. Most characteristics that affect the probability of union membership also plausibly exert some impact on the likelihood of training. In their research on the link between unions and training in Canada, for example, Lemieux and Green (2007) acknowledged the endogeneity problem with the union variable. As an instrument, they tried inter-temporal differences in union density by province, but found it to be too weakly correlated with individual union membership to be effective. ${ }^{11}$ They were left with estimates of the union effect that assumed union membership as exogenous. ${ }^{12}$

Longitudinal data sets with observations on training and other relevant variables make it possible to control for unobserved, time-invariant, individual fixed effects (such as perhaps ability and motivation), leaving the estimate on the union variable unbiased in a training incidence equation. The only evidence in the literature of the existence of upward bias in the union-training effects is provided by Booth et al. (2003), who used the longitudinal BHPS data to find positive selection in a training incidence equation for workers in Britain. They found that a 9.2 per cent higher probability of training for union

\footnotetext{
${ }^{11}$ Similarly, I found inter-state differences in union membership to be too weakly correlated with union membership among females to be an effective instrument. For males, however, the residence in the states of Victoria or New South Wales is correlated with union membership, making it conceivably useful as an instrument. I, nevertheless, find its validity unconvincing. For such a variable to be a valid instrument, one would have to argue that the only effect it has on training is through its relationship with unionism. Residence in states with larger metropolitan areas such as Sydney and Melbourne could affect training in ways other than through union membership. For example, it is reasonable to expect that very large firms (say with 500 or more employees) are concentrated in New South Wales and Victoria to a greater extent that elsewhere in Australia. If very large firms are more likely to train than just large firms (say firms with $100-499$ employees), then the location variable could be correlated with training because of a higher concentration of employment in very large firms and not just unionism. Indeed, Waddoups (2011c) shows that very large firms in Australia train at a significantly greater rate than just large firms using data from the 2001 SET. Unfortunately, the 2005 SET does not distinguish between large and very large firms.

${ }^{12}$ Two studies using the NLSY data from the U.S. were reviewed above. Neither focused specifically on the union-training effect and both estimated training incidence equations assuming an exogenous union variable (Lynch 1992; Veum 1995). Similarly, other previously cited articles using cross-sectional data (i.e. Kennedy et al. 1994, Almeida-Santos and Mumford 2004, 2005) also treat the union variable as exogenous.
} 
members in a cross-sectional model, which treated the union variable as endogenous, fell to 5.2 per cent in a model that controlled for unobserved time-invariant heterogeneity using individual fixed effects. To the author's knowledge no similar study using Australian data exists. If the pattern of results found in Britain holds in Australia, one would expect also to find positive selection into training and upward bias in the uniontraining effect in cross-sectional estimates.

Does evidence exist for positive selection into unions in Australia? Recent research by Cai and Waddoups (2011) established positive selection bias on the union wage effect among men in a study using the Household Income and Labour Dynamics in Australia (HILDA) data. They found that the union wage premium fell from 8.7 per cent to 5.2 per cent for men, a statistically significant decline, and a decline from 4.0 per cent to 1.9 per cent for women, a difference which did not reach conventional levels of significance. Similar research on the union wage effect using the BHPS indicates that female workers and full-time manual male workers were positively selected into unions (Swaffield 2001). There is no guarantee, however, that the process biasing the union wage effect upward would operate in the same manner on the union training effect.

\section{Transferability and Effectiveness}

As reviewed earlier, several studies have addressed the impact of unions on the incidence of training (see Tables 1 and 2). There has been very little emphasis, however, on how union bargaining affects the mix between general and transferable training. Stevens (1994) and Askildsen and Ireland (1994) construct models that delineate firms' incentives to under-invest in transferable skills because of poaching externalities. Although neither 
addresses directly whether unions affect the likelihood of poaching externalities, and thus the mix between specific and transferable training, one could infer it from other work. For example Booth and Chatterji (1998) and Chatterji (2008) hypothesise that by raising bargaining power, unions increase wages and therefore reduce quits. The implied longer tenure of employment from reduced quits logically implies fewer poaching externalities. Indeed, industry studies provide anecdotal evidence of a greater incidence of transferable training in unionised settings. ${ }^{13}$

As for the effectiveness of training based on union status, one can hypothesise about the potential effect of unions in two ways. On the one hand, it would be reasonable to expect that the union voice function may not only increase workers' input into whether training occurs, but also provide an avenue for input into its content and delivery, which in turn could increase workers' perceptions of its effectiveness. Thus under circumstances in which workers have more effective voice, they can reasonably be expected to exhibit more satisfaction with how a given training programme improves job performance. On the other hand, a possible avenue by which unions could reduce perceived effectiveness of training relies on the assumption that union agreements generally include work rules that define job content and definition in an artificially narrow manner. Under such conditions firms may have an incentive to train workers only for narrowly defined tasks, which in turn may cause workers to perceive that training is less effective than it would be otherwise (Kennedy et al. 1994). Another argument along these lines is that to the extent to which training practices are codified into collectively bargained agreements,

\footnotetext{
${ }^{13}$ For example, literature on apprenticeship training in the construction sector argues that such programmes internalise training externalities and thereby provide the institutional setting for workers to acquire more training and a skill mix that more heavily favors general skills. In the U.S. construction labour market, jointly operated union-management apprenticeship programmes produce more journey-level workers and have lower rates of attrition than unilateral employer-sponsored programmes (Bilginsoy 2003).
} 
they may institutionalise training practices that become progressively inconsistent with the way production is performed, which may negatively affect the union members' perceptions of effectiveness.

To determine whether union status affects whether workers report that their training is transferable to other employers, or whether it is perceived to improve job performance, the following two econometric models were estimated:

$$
P(\text { Transferable } \mid \text { Training }=1)=\alpha+\beta(\text { Union Member })+\delta X+\varepsilon,
$$

and

$$
P(\text { Improved Job Perf. } \mid \text { Training }=1)=\alpha+\beta(\text { Union Member })+\delta X+\varepsilon,
$$

where Transferable is the probability that a respondent reports that the training was transferable to other employers, Improved Job Perf. is the probability a respondent reports that training improved job performance, and Training is a dummy variable that takes on the value ' 1 ' if an in-house training course is taken (for the estimations in Table 8). Equation 2 is also estimated where Training takes on the value ' 1 ' if an external training course is taken (see the estimations in Table 9). Both models are also estimated separately for males and females. The other variables and parameters are defined as in equation 1 .

Table 8 about here 
The results for in-house training are located in Table 8. The union effect on transferability is very small and statistically insignificant, which suggests that there is no difference in the probability of training being transferable based on union status. The notion that union members receive more transferable training is thus not supported by the evidence. Other interesting results on transferability suggest that workers with longer tenure are somewhat more likely to participate in transferable training. Longer-tenured workers in all likelihood are less mobile than their shorter-tenured counterparts. A lower chance of turnover in turn should increase the likelihood that firms and workers will judge transferable training investments as potentially more profitable. The other significant result is on the Public Sector variable, which suggests that in-house training in the public sector is less likely to be transferable than training in the private sector.

The results on external training and in-house training are similar. The estimates in Table 9 reveal no union effect on transferability, but the tenure variable is substantially larger for external training. It appears that longer-tenured male and female workers are more likely to judge their external training courses as transferable. To the extent that longer-tenured workers are likely to be less mobile as a result of higher match quality, firm-specific investments, and higher search costs, it is not unreasonable to expect that tenure would be positively related to the probability that an external training course is perceived as transferable. The results also reveal that casual workers are substantially less likely to judge their external work-related training as transferable compared to non-casual workers.

Table 9 about here 
The findings in Table 9 indicate a positive union effect on whether training improves job performance, at least among males. Union members are five percentage points more likely than non-members to report that a training spell improved their job performance. As previously mentioned, perhaps workers in unions have more voice in determining the content of training and how it is delivered, which could reasonably be expected to increase the likelihood that it will be perceived as more productive. Or more optimistically, perhaps the union-provided 'voice' actually creates conditions in which training is more effective and the increased perception of effectiveness is grounded in objective conditions. More research would be required to shed additional light on the nature of the union advantage in this regard.

Another interesting result is found on the firm-size variables for males. In-house training provided by large firms is perceived to be more effective than training provided by smaller firms. If larger firms have more resources to devote to training than smaller firms, then perhaps not only the quantity of training is enhanced, but its quality is as well. The size effect on perceived quality may also provide some insight into the firm sizewage effect as well.

Union status has no effect on whether participation in external training courses is correlated with better job performance. However, longer-tenured workers are more sanguine about the effectiveness of their external training, reporting that it improves job performance; the effect is especially strong among females. Casual and part-time male workers are less likely to report that training improves job performance than their noncasual and full-time counterparts. The same cannot be said about females, however. 
Finally, male workers in the public sector are more likely to perceive that their training improves job performance, but the same does not hold for female public sector workers.

\section{Conclusions}

A major premise of the study is that job-related training is an important aspect of skill formation, and that the impact of union membership on various aspects of training, is therefore, an important question to address. Given the premise, I examined three dimensions of the union training effect: incidence, transferability, and efficacy. A major finding is that, even after controlling for a full range of observable characteristics, union membership remains positively correlated with the incidence of in-house training. Although such a correlation is generally found in data from the U.K., results have been mixed in the U.S. and the only similar study from Canada shows, if anything, a small negative union-training effect.

The positive correlation between union membership and the incidence of employer-provided training runs counter to standard human capital theory, which predicts that higher union wages unions will reduce the incidence of training. Instead, the results are more consistent with competing theories related to imperfect competition (e.g. Acemoglu and Pischke 1999; Booth and Chatterji 1998; Booth, Chatterji and Zoega 2002; Chatterji 2008). As with most other studies on union training effects, the results here may be affected by endogeneity in the union variable that may bias the estimated union effect upwards. Of course, such upward bias may be offset by a downward bias from union-influenced employment policies that spill over to non-members. The omitted 
variable in this case is 'union activity'. Either way one must be cautious in making strong claims of causation between union membership and incidence of training.

The findings also indicate that a large majority of trainees perceive that the skills obtained during in-house and external training are transferable to other employers. Results of the data analysis, however, revealed no union effect on the mix between specific and transferable training. It is more difficult to interpret this result than the findings on incidence, in part, because the theory is under-developed. Although there has been significant theoretical work exploring the theoretical implications of unions on training incidence, there has been no such work on the relationship between unions and the mix between transferable and specific training. More work in this area seems to be warranted. As is often the case, however, the data to test any implications of the theory would likely remain imperfect. In the SET data, for example, we are uncertain of the degree to which the skills in question are actually transferable, as the question contains a counterfactual, and the respondents had not necessarily had any direct experience with transferability.

With regard to the efficacy of training from the workers' perspective, the findings suggest that a vast majority of workers perceive that training improved their job performance. Although there are reasonable arguments that union presence could either increase perceptions of effectiveness through 'voice' or decrease perceptions of effectiveness by advocating for work organisations charaterised by artificially narrow job classifications or by institutionalising training practices inconsistent with the production process, the empirical findings of a positive association only holds for males taking inhouse training courses. Similar to the topic of transferability, there has not been much 
theoretical work addressing the relationship between unions and effectiveness of training. Although one would expect that more effective training would raise productivity and thus wages, and the returns to training as measured by higher wages has received a lot more attention in the literature. 


\section{References}

Acemoglu, D. and Pischke, J.S. (1999). 'The structure of wages and investment in general training'. Journal of Political Economy, 107: 539-72.

Almeida-Santos , F. and Mumford, K.A. (2004). 'Employee training in Australia: Evidence from AWIRS'. The Economic Record, 80: S53-S64.

Almeida-Santos , F. and Mumford, K.A. (2005). 'Employee training and wage compression in Britain'. The Manchester School, 73: 321-42.

Angrist, J.D. and Krueger A.B. (2001). 'Instrumental variables and the search for indentification: from supply and demand to natural experiments'. Journal of Economic Perspectives, 15: 69-85.

Asklildsen, J.E. and Ireland N.E. (1993). 'Human capital, property rights, and labour managed firms'. Oxford Economic Papers, 45: 229-42.

Australian Bureau of Statistics [ABS] (2006). Education and Training Experience, Australia, Catalogue 6278.0 Canberra: Australian Bureau of Statistics.

Barron, J. M., Black, D.A., Loewenstein, M.A. (1987). ‘Employer size: the implications for search, training, capital investment, starting wages, and wage growth'. Journal of Labor Economics, 5: 76-89.

Becker, G. S. (1962). 'Investment in human capital: a theoretical analysis'. Journal of Political Economy, 70 Part 2: 9-49.

Bilginsoy, C. (2003). 'The hazards of training: attrition and retention in construction industry apprenticeship programs'. Industrial and Labor Relations Review 57: 5467. 
Booth, A.L. (1991). 'Job related formal training: who receives it and what is it worth?' Oxford Bulletin of Economics and Statistics, 53: 281-294.

Booth, A.L. and Bryan, M.L. (2005). 'Testing some predictions of human capital theory: new training and evidence from Britain'. The Review of Economics and Statistics, 87: 391-94.

Booth, A.L. and Chatterji, M. (1998). 'Unions and efficient training'. The Economic Journal, 108: 328-43.

Booth, A. L., Francesconi, M. and Zoega, G. (2002). 'Oligopsony, institutions, and the efficiency of general training,' Discussion Paper no. 618, Institute for the Study of Labor (IZA).

Booth, A. L., Francesconi, M. and Zoega, G. (2003). 'Unions, work related training, and wages: evidence from British men'. Industrial \& Labor Relations Review, 57: 6891.

Booth, A.L. and Katic, P. (2011). 'Men at work in a land down-under: testing some predictions of human capital theory'. British Journal of Industrial Relations, 49: $1-24$.

Cai, L. and Waddoups, C.J. (2011). 'Union wage effects in Australia: evidence from panel data'. British Journal of Industrial Relations, 49: s279-s305.

Cai, L. and Liu, A. Y. C. (2008). 'Union wage effects in Australia: are there variations along the distribution?' Economic Record, 84 (267): 496-510

Chatterji, M. (2008). 'Training hold up and social labour markets'. Labour Economics, 15: 202-14.

Freeman, R. B. and Medoff, J.L. (1984). What Do Unions Do? New York: Basic. 
Green, D. A. and Lemiuex, T. (2007). 'The impact of unionization on the incidence and sources of payment for training in Canada'. Empirical Economics, 32: 465-489.

Hashimoto, M. (1981). 'Firm-specific human capital as a shared investment'. American Economic Review, 71: 475-82.

Kennedy, S., Drago, R., Sloan, J., and Wooden, M. (1994). 'The effect of trade unions on the provision of training: Australian evidence'. British Journal of Industrial Relations, 32: 565-80.

Lynch, L. M. (1992). 'Private sector earnings and the training of young workers'. American Economic Review, 82: 299-312.

Mincer, J. (1993). 'Job training, wage growth and labor turnover'. In Studies in Human Capital: Collected Essays of Jacob Mincer, Vol. I. Edward Elgar: Brookfield, VT, 239-62.

Osterman, P. (1995). 'Skill training and work organization in American establishments'. Industrial Relations, 34: 125-46.

Stevens, M. (1994). 'A theoretical model of on-the-job training with imperfect competition'. Oxford Economic Papers, 46: 537-62.

Swaffield, J. K. (2001). 'Does measurement error bias fixed-effects estimates of the union wage effect?' Oxford Bulletin of Economics and Statistics, 63: 437-57.

Veum, J. (1995). 'Sources of training and their impact on wages'. Industrial \& Labor Relations Review, 48: 812-26.

Waddoups, C. J. (2011a). 'Employer-sponsored training and longer-tenured workers: evidence from Australia'. Unpublished manuscript. 
Waddoups, C.J. (2011b). 'Narrowly-defined training classifications and training-wage effects: evidence from Australia'. Labour \& Industry, 22: 103-116.

Waddoups, C.J. (2011c). 'Firm size and employer sponsored training:new evidence on intensity and training type from Australia'. Journal of Labor Research, 32: 390413. 
TABLE 1

Models of Employer-Sponsored Training and Associated Predictions

\begin{tabular}{ll}
\hline Conceptual Model & \multicolumn{1}{c}{ Predictions on Union Effects } \\
\hline $\begin{array}{l}\text { Human Capital Theory (e.g. Becker } \\
\text { 1962) }\end{array}$ & $\begin{array}{l}\text { Reduces the likelihood of training. Wage floors in } \\
\text { union contracts reduce ability of liquidity } \\
\text { constrained workers to finance general training with } \\
\text { lower wages. }\end{array}$ \\
$\begin{array}{ll}\text { Imperfect Competition (Acemoglu and } \\
\text { Pischke 1999) }\end{array}$ & $\begin{array}{l}\text { Prediction on training is ambiguous. Wage } \\
\text { compression increases the likelihood that firms will } \\
\text { offer general training and decreases the likelihood } \\
\text { that workers will find training profitable. }\end{array}$ \\
& $\begin{array}{l}\text { Increases the likelihood of training. Unions raise } \\
\text { bargaining power of trained workers, which raises } \\
\text { wages and thereby reduces quits. With fewer quits } \\
\text { firms are less likely to lose training investments, } \\
\text { thus become more likely to train. With industry-wide } \\
\text { bargaining, union internalise training externalities, } \\
\text { Chatterji 1998; Booth, Francesconi, } \\
\text { and Zoega 2002; Chatterji 2008) }\end{array}$ \\
$\begin{array}{l}\text { which increases the likelihood of training. } \\
\text { Increases the likelihood of training. Unions provide } \\
\text { workers bargaining power, which workers use to }\end{array}$ \\
$\begin{array}{ll}\text { increase compensation, part of which is taken in } \\
\text { the form of increased general training. }\end{array}$ \\
\hline
\end{tabular}


TABLE 2

Summary of Empirical Literature Review

\begin{tabular}{|c|c|c|c|}
\hline Authors & Definition of Training & Data Source & Union Variable/Impact \\
\hline Mincer (1993) & $\begin{array}{l}\text { Length of time with employer until fully } \\
\text { trained. }\end{array}$ & $\begin{array}{l}\text { United States; Panel Study of } \\
\text { Income Dynamics, 1976, 1978; } \\
\text { individual Level. }\end{array}$ & $\begin{array}{l}\text { Union membership; } \\
\text { negative, statistically sig. }\end{array}$ \\
\hline Barron, Black, and Loewenstein (1987) & $\begin{array}{l}\text { Series of variables measuring employer- } \\
\text { provided training provided to last person } \\
\text { hired. }\end{array}$ & $\begin{array}{l}\text { United States; Employment } \\
\text { Opportunity Pilot Project, 1981; } \\
\text { employer level. }\end{array}$ & $\begin{array}{l}\text { Proportion of workforce } \\
\text { unionised, negative, not } \\
\text { statistically sig. }\end{array}$ \\
\hline Green and Lemiuex (2007) & $\begin{array}{l}\text { Series of variables: programme training, } \\
\text { course training, firm specific, and general } \\
\text { training. }\end{array}$ & $\begin{array}{l}\text { Canadian Adult Education and } \\
\text { Training Survey, 1997; individual } \\
\text { level. }\end{array}$ & $\begin{array}{l}\text { Union member; negative, } \\
\text { statistically sig. }\end{array}$ \\
\hline Booth (1991) & $\begin{array}{l}\text { Any formal employer-provided, job-related } \\
\text { training in past two years. }\end{array}$ & \begin{tabular}{|l} 
British Social Attitudes Survey, \\
1987; individual level.
\end{tabular} & $\begin{array}{l}\text { Unions in workplace, positive } \\
\text { stat. sig. }\end{array}$ \\
\hline Booth, Francesconi, and Zoega (2003) & $\begin{array}{l}\text { Courses, schemes in previous year to } \\
\text { improve skills on current job. }\end{array}$ & $\begin{array}{l}\text { British Household Panel Survey, } \\
\text { 1991-96; individual level. }\end{array}$ & $\begin{array}{l}\text { Union coverage, positive, } \\
\text { statistically sig. }\end{array}$ \\
\hline Lynch (1992) & $\begin{array}{l}\text { Company training on the job lasting more } \\
\text { than a month. }\end{array}$ & $\begin{array}{l}\text { United States; National } \\
\text { Longitudinal Study of Youth, 1980- } \\
\text { 83, individual level. } \\
\end{array}$ & $\begin{array}{l}\text { Union member, positive, } \\
\text { statistically sig. }\end{array}$ \\
\hline Veum (1995) & $\begin{array}{l}\text { Company training on the job regardless of } \\
\text { duration. }\end{array}$ & $\begin{array}{l}\text { United States; National } \\
\text { Longitudinal Study of Youth, 1986- } \\
\text { 90, individual level. }\end{array}$ & $\begin{array}{l}\text { Union member, positive, } \\
\text { statistically sig. }\end{array}$ \\
\hline Osterman (1995) & $\begin{array}{l}\text { Fraction of core non-managerial, non- } \\
\text { supervisory employees who received } \\
\text { training off the job. }\end{array}$ & $\begin{array}{l}\text { United States; representative } \\
\text { sample of establishments, 1992; } \\
\text { establishment level. }\end{array}$ & $\begin{array}{l}\text { Existence of a union in the } \\
\text { establishment, positive, } \\
\text { statistically sig. }\end{array}$ \\
\hline Kennedy et al. (1994) & $\begin{array}{l}\text { Two variables: formal in-house training } \\
\text { courses and formal external training } \\
\text { during the previous year. }\end{array}$ & $\begin{array}{l}\text { Australian Workplace Industrial } \\
\text { Relations Survey, 1989-90; } \\
\text { combined establishment and } \\
\text { individual level. }\end{array}$ & $\begin{array}{l}\text { Individual union membership } \\
\text { not stat. sig. A union activity } \\
\text { indicator positive and stat. } \\
\text { sig. }\end{array}$ \\
\hline Almeida-Santos and Mumford (2004) & $\begin{array}{l}\text { Whether workers received employer- } \\
\text { provided training in the previous year }\end{array}$ & $\begin{array}{l}\text { Australian Workplace Industrial } \\
\text { Relations Survey, 1995-96; } \\
\text { combined establishment and } \\
\text { individual level. }\end{array}$ & $\begin{array}{l}\text { Union membership positive, } \\
\text { not stat. sig. Recognised } \\
\text { unions in workplace negative } \\
\text { not stat. sig. }\end{array}$ \\
\hline
\end{tabular}


TABLE 3

Incidence of Job Training, Transferability, Efficacy, and Cost (Percent)

\begin{tabular}{|c|c|c|c|c|}
\hline & \multicolumn{2}{|c|}{ Male } & \multicolumn{2}{|c|}{ Female } \\
\hline & Union & Non-Union & Union & Non-Union \\
\hline \multicolumn{5}{|l|}{ Type of Training } \\
\hline Percent engaging in any Training & 65.1 & 50.8 & 72.0 & 50.3 \\
\hline Percent engaging in Internal Training ${ }^{1}$ & 50.4 & 30.4 & 59.4 & 32.7 \\
\hline Percent engaging in External Training & 27.6 & 29.2 & 30.8 & 26.9 \\
\hline Number in Sample & 1,706 & 4,425 & 1,648 & 4,441 \\
\hline \multicolumn{5}{|l|}{ Conditional on Receiving Int. Training } \\
\hline Percent Reporting Transferability & 89.7 & 91.1 & 93.1 & 92.7 \\
\hline Percent Reporting Improved Job Perf. & 93.7 & 87.5 & 93.1 & 90.8 \\
\hline Percent Reporting Costs Incurred & 2.2 & 2.0 & 5.5 & 2.8 \\
\hline Number in Sample & 255 & 914 & 211 & 787 \\
\hline \multicolumn{5}{|l|}{ Conditional on Receiving Ext. Training } \\
\hline Percent Reporting Transferability & 91.8 & 87.0 & 91.0 & 88.7 \\
\hline Percent Reporting Improved Job Perf. & 86.4 & 80.8 & 88.4 & 84.1 \\
\hline Percent Reporting Costs Incurred & 14.1 & 16.1 & 20.1 & 19.8 \\
\hline Number in Sample & 636 & 950 & 255 & 914 \\
\hline \multicolumn{5}{|l|}{ Conditional on Any Receiving Training } \\
\hline Percent Reporting Transferability & 91.6 & 90.8 & 94.1 & 92.2 \\
\hline Percent Reporting Improved Job Perf. & 92.7 & 86.6 & 93.5 & 90.8 \\
\hline Number in Sample & 1,113 & 2,259 & 1,180 & 2,247 \\
\hline \multicolumn{5}{|c|}{$\begin{array}{l}\text { Source: The data used to generate the estimates were obtained from the expanded } \\
\text { Survey of Education and Training, } 2005 \text { gathered by the Australian Bureau of } \\
\text { Statistics. Excluded are those not currently working for their main period employer, } \\
\text { the self employed or those working for their own business, and full time students. The } \\
\text { data set contains } 6,131 \text { males and } 6,086 \text { females. }\end{array}$} \\
\hline \multicolumn{5}{|c|}{$\begin{array}{l}{ }^{1} \text { Defined as the percent engaging in at least one in-house training course in the } \\
\text { previous } 12 \text { months. }\end{array}$} \\
\hline $\begin{array}{l}{ }^{2} \text { Defined as the percent engaging in at l } \\
\text { previous } 12 \text { months. }\end{array}$ & t one ex & ernal training & course i & \\
\hline
\end{tabular}


TABLE 4

Summary Statistics by Union Membership Status and Gender

\begin{tabular}{|c|c|c|c|c|}
\hline & \multicolumn{2}{|c|}{ Male } & \multicolumn{2}{|c|}{ Female } \\
\hline & Union & Non-union & Union & Non-union \\
\hline Age in Years & $\begin{array}{c}41.3 \\
(11.47)\end{array}$ & $\begin{array}{c}37.3 \\
(12.40)\end{array}$ & $\begin{array}{c}41.9 \\
(11.36)\end{array}$ & $\begin{array}{c}37.8 \\
(12.09)\end{array}$ \\
\hline Duration with Main Period Emplr. & $\begin{array}{c}10.9 \\
(8.70)\end{array}$ & $\begin{array}{c}5.8 \\
(6.45)\end{array}$ & $\begin{array}{c}9.6 \\
(7.76)\end{array}$ & $\begin{array}{c}5.4 \\
(5.75)\end{array}$ \\
\hline Duration in Occupation & $\begin{array}{c}12.0 \\
(8.95)\end{array}$ & $\begin{array}{c}8.0 \\
(7.90)\end{array}$ & $\begin{array}{c}11.2 \\
(8.76)\end{array}$ & $\begin{array}{c}7.5 \\
(7.52)\end{array}$ \\
\hline Bachelors Degree & 0.096 & 0.142 & 0.218 & 0.159 \\
\hline Completed Year 12 & 0.151 & 0.198 & 0.137 & 0.215 \\
\hline Completed Year 11 or less & 0.275 & 0.252 & 0.236 & 0.295 \\
\hline ize: Fewer than 20 Workers & 0.062 & 0.271 & 0.057 & 0.264 \\
\hline Firm Size: Bet. 20 and 99 Workers & 0.101 & 0.170 & 0.116 & 0.162 \\
\hline Firm Size: 100 or More Workers & 0.789 & 0.498 & 0.776 & 0.512 \\
\hline Public Sector & 0.373 & 0.147 & 0.505 & 0.204 \\
\hline Casual & 0.060 & 0.214 & 0.093 & 0.305 \\
\hline Part Time & 0.087 & 0.148 & 0.397 & 0.494 \\
\hline Number in Sample & 1,706 & 4,425 & 1,648 & 4,441 \\
\hline $\begin{array}{l}\text { Source: The data used to generate } \\
\text { Survey of Education and Training, } \\
\text { Statistics. Excluded are those not } \\
\text { the self employed or those working } \\
\text { The data set contains } 6,131 \text { males }\end{array}$ & $\begin{array}{l}\text { estima } \\
\text { gather }\end{array}$ & $\begin{array}{l}\text { were obta } \\
\text { by the Au }\end{array}$ & $\begin{array}{l}\text { d from th } \\
\text { lian Burs }\end{array}$ & $\begin{array}{l}\text { expanded } \\
\text { u of } \\
\text { mployer, } \\
\text { udents. }\end{array}$ \\
\hline
\end{tabular}


TABLE 5

Probability of In-House Training Organized by Employer, Marginal Effects Probits

\begin{tabular}{|c|c|c|c|c|c|c|}
\hline & \multicolumn{3}{|c|}{ Males } & \multicolumn{3}{|c|}{ Females } \\
\hline & Spec. 1 & Spec. 2 & Spec. 3 & Spec. 1 & Spec. 2 & Spec. 3 \\
\hline Variable & $\mathrm{dF} / \mathrm{dx}$ t stat. & $\mathrm{dF} / \mathrm{dx}$ t stat. & $\mathrm{dF} / \mathrm{dx}$ t stat. & $\mathrm{dF} / \mathrm{dx}$ t stat. & $\mathrm{dF} / \mathrm{dx}$ t stat. & $\mathrm{dF} / \mathrm{dx}$ t stat. \\
\hline Union & 0.1827 (12.35) & $0.0866(5.62)$ & $0.0828(5.19)$ & $0.2304(15.09)$ & $0.1410(8.74)$ & $0.1345(8.09)$ \\
\hline Age & $0.0205(5.60)$ & $0.0119(2.97)$ & $0.0096(2.34)$ & $0.0045(1.20)$ & $-0.0017(0.41)$ & $-0.0022(0.53)$ \\
\hline Age Squared & $-0.0003(5.79)$ & $-0.0002(3.47)$ & $-0.0002(3.00)$ & $-0.0001(1.17)$ & $0.0000(0.53)$ & $0.0000(0.53)$ \\
\hline Tenure with Employer & $0.0064(1.85)$ & $-0.0025(0.71)$ & $-0.0018(0.49)$ & 0.0107 (2.88) & $-0.0024(0.62)$ & $-0.0030(0.78)$ \\
\hline Tenure Squared & $0.0001(0.68)$ & $0.0002(1.56)$ & $0.0002(1.28)$ & $-0.0003(1.85)$ & $0.0000(0.27)$ & $0.0001(0.41)$ \\
\hline Tenure in Occupation & $-0.0056(1.62)$ & $-0.0045(1.27)$ & $-0.0048(1.36)$ & $-0.0019(0.53)$ & $0.0017(0.45)$ & $0.0022(0.60)$ \\
\hline Tenure (Occ.) Squared & $0.0001(0.41)$ & $0.0001(0.66)$ & $0.0001(0.83)$ & $-0.0001(0.52)$ & $-0.0002(1.11)$ & $-0.0002(1.34)$ \\
\hline Firm Size: Bet. 20 and 99 Workers & & $0.1350(5.80)$ & $0.1307(5.54)$ & & $0.1271(5.60)$ & $0.1249(5.42)$ \\
\hline Firm Size: More than 100 Workers & & $0.3127(18.95)$ & $0.2963(17.27)$ & & $0.2661(15.87)$ & $0.2610(15.19)$ \\
\hline Casual & & $-0.0798(3.59)$ & $-0.0734(3.27)$ & & $-0.1350(7.30)$ & $-0.1133(5.86)$ \\
\hline Public Sector & & $0.1389(8.04)$ & 0.0817 (3.43) & & $0.1274(7.80)$ & $0.0845(4.17)$ \\
\hline Part-Time & & $-0.0173(0.71)$ & $-0.0202(0.81)$ & & $0.0071(0.47)$ & $-0.0079(0.50)$ \\
\hline Education Dummies & Yes & Yes & Yes & Yes & Yes & Yes \\
\hline Demographic Dummies & No & Yes & Yes & No & Yes & Yes \\
\hline State, Occ., Ind. Dummies & No & No & Yes & No & No & Yes \\
\hline Predicted Prob. at Means & 0.350 & 0.333 & 0.329 & 0.399 & 0.379 & 0.374 \\
\hline Number in Sample & 6131 & 6131 & 6131 & 6086 & 6086 & 6086 \\
\hline
\end{tabular}

Source: The data used to generate the estimates were obtained from the expanded Survey of Education and Training, 2005 gathered by the Australian Bureau of Statistics. Excluded are those not currently working for their main period employer, the self employed or those working for their own business, and full time students. 
TABLE 6

Probability of External Training, Marginal Effects Probits

\begin{tabular}{|c|c|c|c|c|c|c|}
\hline & \multicolumn{3}{|c|}{ Males } & \multicolumn{3}{|c|}{ Females } \\
\hline & Spec. 1 & Spec. 2 & Spec. 3 & Spec. 1 & Spec. 2 & Spec. 3 \\
\hline Variable & dF/dx t stat. & $\mathrm{dF} / \mathrm{dx}$ t stat. & $\mathrm{dF} / \mathrm{dx}$ t stat. & $\mathrm{dF} / \mathrm{dx}$ t stat. & $\mathrm{dF} / \mathrm{dx}$ t stat. & $\mathrm{dF} / \mathrm{dx}$ t stat. \\
\hline Union & $-0.0216(1.57)$ & $-0.0356(2.50)$ & $-0.0262(1.78)$ & $0.0098(0.71)$ & $-0.0092(0.64)$ & $-0.0081(0.55)$ \\
\hline Age & $0.0132(3.84)$ & 0.0065 (1.77) & $0.0062(1.64)$ & $0.0116(3.31)$ & 0.0110 (2.99) & $0.0101(2.69)$ \\
\hline Age Squared & $-0.0002(3.92)$ & $-0.0001(1.99)$ & $-0.0001(2.01)$ & $-0.0001(2.47)$ & $-0.0001(2.14)$ & $-0.0001(2.05)$ \\
\hline Tenure with Employer & $0.0027(0.82)$ & $-0.0014(0.43)$ & $0.0003(0.11)$ & $0.0006(0.19)$ & $-0.0035(1.03)$ & $-0.0049(1.43)$ \\
\hline Tenure Squared & $0.0000(0.23)$ & $0.0001(0.58)$ & $0.0000(0.16)$ & $-0.0001(0.91)$ & $0.0000(0.16)$ & $0.0001(0.43)$ \\
\hline Tenure in Occupation & $-0.0052(1.61)$ & $-0.0063(1.96)$ & $-0.0074(2.29)$ & $-0.0014(0.44)$ & $-0.0013(0.40)$ & $0.0000(0.01)$ \\
\hline Tenure (Occ.) Squared & $0.0001(1.20)$ & $0.0002(1.57)$ & $0.0002(1.90)$ & $0.0000(0.08)$ & $0.0000(0.11)$ & $-0.0001(0.80)$ \\
\hline Firm Size: Fewer than 20 Workers & & $0.0380(1.95)$ & $0.0372(1.87)$ & & $0.0629(3.22)$ & 0.0609 (3.08) \\
\hline Firm Size: Bet. 20 and 99 Workers & & $0.0242(1.59)$ & $0.0338(2.13)$ & & $-0.0267(1.77)$ & $-0.0223(1.44)$ \\
\hline Casual & & $-0.0944(4.83)$ & $-0.0962(4.91)$ & & $-0.1067(6.65)$ & $-0.0824(4.93)$ \\
\hline Public Sector & & $0.0134(0.85)$ & $-0.0287(1.31)$ & & $0.0392(2.67)$ & $-0.0492(2.86)$ \\
\hline Part-Time & & $-0.0541(2.47)$ & $-0.0301(1.31)$ & & $-0.0266(2.02)$ & $-0.0285(2.07)$ \\
\hline Education Dummies & Yes & Yes & Yes & Yes & Yes & Yes \\
\hline Demographic Dummies & No & Yes & Yes & No & Yes & Yes \\
\hline State, Occ., Ind. Dummies & No & No & Yes & No & No & Yes \\
\hline Predicted Prob. at Means & 0.285 & 0.282 & 0.276 & 0.277 & 0.273 & 0.263 \\
\hline Number in Sample & 6131 & 6131 & 6131 & 6086 & 6086 & 6086 \\
\hline
\end{tabular}

Source: The data used to generate the estimates were obtained from the expanded Survey of Education and Training, 2005 gathered by the

Australian Bureau of Statistics. Excluded are those not currently working for their main period employer, the self employed or those working for their own business, and full time students. 
TABLE 7

Probability of Either In-House or External Training or Both, Marginal Effects Probits

\begin{tabular}{|c|c|c|c|c|c|c|}
\hline & \multicolumn{3}{|c|}{ Males } & \multicolumn{3}{|c|}{ Females } \\
\hline & Spec. 1 & Spec. 2 & Spec. 3 & Spec. 1 & Spec. 2 & Spec. 3 \\
\hline Variable & Coeff. t stat. & Coeff. t stat. & Coeff. t stat. & Coeff. t stat. & Coeff. t stat. & Coeff. t stat. \\
\hline Union & $0.1827(8.50)$ & $0.0465(2.82)$ & $0.0470(2.74)$ & $0.1837(11.94)$ & $0.1052(6.34)$ & $0.1055(6.08)$ \\
\hline Age & $0.0205(6.36)$ & $0.0125(3.05)$ & $0.0103(2.44)$ & 0.0115 (3.04) & $0.0071(1.74)$ & $0.0066(1.55)$ \\
\hline Age Squared & $-0.0003(6.58)$ & $-0.0002(3.62)$ & $-0.0002(3.23)$ & $-0.0001(2.73)$ & $-0.0001(1.34)$ & $-0.0001(1.35)$ \\
\hline Tenure with Employer & $0.0064(1.51)$ & $-0.0043(1.14)$ & $-0.0025(0.65)$ & $0.0082(2.15)$ & $-0.0055(1.38)$ & $-0.0077(1.91)$ \\
\hline Tenure Squared & $0.0001(0.58)$ & $0.0002(1.62)$ & $0.0002(1.19)$ & $-0.0003(1.90)$ & $0.0001(0.32)$ & $0.0001(0.85)$ \\
\hline Tenure in Occupation & $-0.0056(1.75)$ & $-0.0069(1.86)$ & $-0.0078(2.06)$ & $-0.0011(0.29)$ & $0.0019(0.50)$ & $0.0033(0.85)$ \\
\hline Tenure (Occ.) Squared & $0.0001(0.77)$ & $0.0002(1.35)$ & 0.0002 (1.63) & $-0.0001(0.80)$ & $-0.0002(1.34)$ & $-0.0003(1.94)$ \\
\hline Firm Size: Bet. 20 and 99 Workers & & $0.1034(4.96)$ & $0.1022(4.80)$ & & $0.1091(5.23)$ & $0.1111(5.18)$ \\
\hline Firm Size: More than 100 Workers & & $0.2424(14.51)$ & $0.2403(13.72)$ & & $0.1766(10.57)$ & $0.1767(10.14)$ \\
\hline Casual & & $-0.1198(5.29)$ & $-0.1207(5.23)$ & & $-0.1796(9.55)$ & $-0.1471(7.42)$ \\
\hline Public Sector & & $0.1348(7.27)$ & $0.0702(2.69)$ & & $0.1249(7.42)$ & $0.0258(1.19)$ \\
\hline Part-Time & & $-0.0645(2.58)$ & $-0.0453(1.73)$ & & $-0.0040(0.26)$ & $-0.0171(1.05)$ \\
\hline Education Dummies & Yes & Yes & Yes & Yes & Yes & Yes \\
\hline Demographic Dummies & No & Yes & Yes & No & Yes & Yes \\
\hline State, Occ., Ind. Dummies & No & No & Yes & No & No & Yes \\
\hline Predicted Prob. at Means & 0.554 & 0.556 & 0.557 & 0.570 & 0.572 & 0.570 \\
\hline Number in Sample & 6131 & 6131 & 6131 & 6089 & 6089 & 6089 \\
\hline
\end{tabular}

Source: The data used to generate the estimates were obtained from the expanded Survey of Education and Training, 2005 gathered by the Australian Bureau of Statistics. Excluded are those not currently working for their main period employer, the self employed or those working for their own business, and full time students. 
TABLE 8

The Impact of Union Membership on Transferability and Improvement of Job Performance: Internal Training

\begin{tabular}{lrr|rr}
\hline & \multicolumn{2}{c|}{ Transferability $^{1}$} & \multicolumn{2}{c}{ Improve Job Performance $^{2}$} \\
\hline & \multicolumn{2}{c|}{ Male } & Female & \multicolumn{2}{c}{ Male } & \multicolumn{1}{c}{ Female } \\
\hline Union & dF/dx t stat. & dF/dx t stat. & \multicolumn{1}{c}{ dF/dx t stat. } & \multicolumn{1}{c}{ dF/dx t stat. } \\
Age & $0.0151(0.93)$ & $0.0062(0.47)$ & $0.0503(3.20)$ & $0.0199(1.39)$ \\
Age Squared & $0.0041(0.92)$ & $0.0050(1.39)$ & $0.0057(1.28)$ & $-0.0007(0.17)$ \\
Tenure with Employer & $-0.0001(1.35)$ & $-0.0001(1.48)$ & $-0.0001(1.36)$ & $0.0000(0.15)$ \\
Tenure Squared & $0.0072(1.84)$ & $0.0043(1.35)$ & $0.0024(0.70)$ & $0.0026(0.74)$ \\
Tenure in Occupation & $-0.0002(1.58)$ & $-0.0002(1.35)$ & $0.0000(0.04)$ & $-0.0002(1.15)$ \\
Tenure (Occ.) Squared & $-0.0060(1.58)$ & $0.0003(0.10)$ & $-0.0058(1.63)$ & $-0.0018(0.52)$ \\
Firm Size: Bet. 20 and 99 Workers & $0.0002(1.22)$ & $-0.0001(0.52)$ & $0.0001(0.81)$ & $0.0001(0.65)$ \\
Firm Size: More than 100 Workers & $0.0260(0.90)$ & $-0.0014(0.05)$ & $0.0194(0.78)$ & $0.0172(0.71)$ \\
Casual & $0.0205(0.77)$ & $-0.0120(0.65)$ & $0.0493(2.06)$ & $0.0142(0.70)$ \\
Public Sector & $0.0052(0.19)$ & $0.0063(0.35)$ & $0.0144(0.63)$ & $0.0035(0.18)$ \\
Part-Time & $-0.0817(3.47)$ & $-0.0414(2.26)$ & $0.0107(0.48)$ & $0.0011(0.06)$ \\
& $0.0042(0.14)$ & $-0.0154(1.04)$ & $-0.0252(0.85)$ & $-0.0372(2.46)$ \\
Predicted Prob. at Means & & & & \\
Number in Sample & 0.917 & 0.936 & 0.921 & 0.929 \\
Source: The data & 1501 & 1617 & 1586 & 1642 \\
\hline
\end{tabular}

Source: The data used to generate the estimates were obtained from the expanded Survey of Education and Training, 2005 gathered by the Australian Bureau of Statistics. Excluded are those not currently working for their main period employer, the self employed or those working for their own business, and full time students.

${ }^{1}$ Transferability: respondents' perception on whether the training received is transferable to another employer.

${ }^{2}$ Improve Job Performance: respondents' perception on whether the training improved their job performance. 
TABLE 9

The Impact of Union Membership on Transferability and Improvement of Job Performance: External Training

\begin{tabular}{lcc|rr}
\hline & \multicolumn{2}{c|}{ Transferability } & \multicolumn{2}{c}{ Improve Job Performance } \\
\hline & \multicolumn{2}{c|}{ Male } & Female & \multicolumn{2}{c}{ Male } & \multicolumn{1}{c}{ Female } \\
\hline & $\mathrm{dF} / \mathrm{d}$ x t stat. & $\mathrm{dF} / \mathrm{d}$ x t stat. & $\mathrm{dF} / \mathrm{dx}$ t stat. & \multicolumn{1}{c}{$\mathrm{dF} / \mathrm{dx}$ t stat. } \\
\hline Union & $0.0054(0.27)$ & $-0.0051(0.22)$ & $0.0234(0.85)$ & $-0.0125(0.42)$ \\
Age & $0.0035(0.76)$ & $-0.0044(0.81)$ & $0.0085(1.29)$ & $0.0049(0.78)$ \\
Age Squared & $0.0000(0.86)$ & $0.0001(0.91)$ & $-0.0001(1.16)$ & $-0.0001(0.80)$ \\
Tenure with Employer & $0.0216(4.51)$ & $0.0143(2.80)$ & $0.0092(1.51)$ & $0.0170(2.76)$ \\
Tenure Squared & $-0.0007(3.61)$ & $-0.0004(1.79)$ & $-0.0002(0.81)$ & $-0.0006(2.29)$ \\
Tenure in Occupation & $0.0063(1.38)$ & $0.0028(0.66)$ & $-0.0054(0.92)$ & $-0.0017(0.31)$ \\
Tenure (Occ.) Squared & $-0.0003(1.55)$ & $-0.0002(1.04)$ & $0.0001(0.49)$ & $0.0150(0.51)$ \\
Firm Size: Bet. 20 and 99 Workers & $-0.0157(0.68)$ & $-0.0346(1.29)$ & $-0.0060(0.19)$ & $-0.0116(0.43)$ \\
Firm Size: More than 100 Workers & $-0.0097(0.51)$ & $-0.0387(1.72)$ & $-0.0039(0.15)$ & $-0.0366(1.24)$ \\
Casual & $-0.1154(4.05)$ & $-0.0741(2.75)$ & $-0.1266(3.29)$ & $-0.0409(1.24)$ \\
Public Sector & $0.0302(1.01)$ & $-0.0117(0.43)$ & $0.1448(3.81)$ & $-0.0796(3.02)$ \\
Part-Time & $-0.1031(3.13)$ & $-0.0420(1.93)$ & $-0.1336(2.90)$ & $-0.0211(0.63)$ \\
& & & & \\
Predicted Prob. at Means & 0.926 & 0.919 & 0.858 & 0.883 \\
Number in Sample & 1129 & 976 & 1162 & 989 \\
\hline
\end{tabular}

Source: The data used to generate the estimates were obtained from the expanded Survey of Education and Training, 2005 gathered by the Australian Bureau of Statistics. Excluded are those not currently working for their main period employer, the self employed or those working for their own business, and full time students. 'Transferability: respondents' perception on whether the training received is transferable to another employer. ${ }^{2}$ Improve Job Performance: respondents' perception on whether the training improved their job performance. 